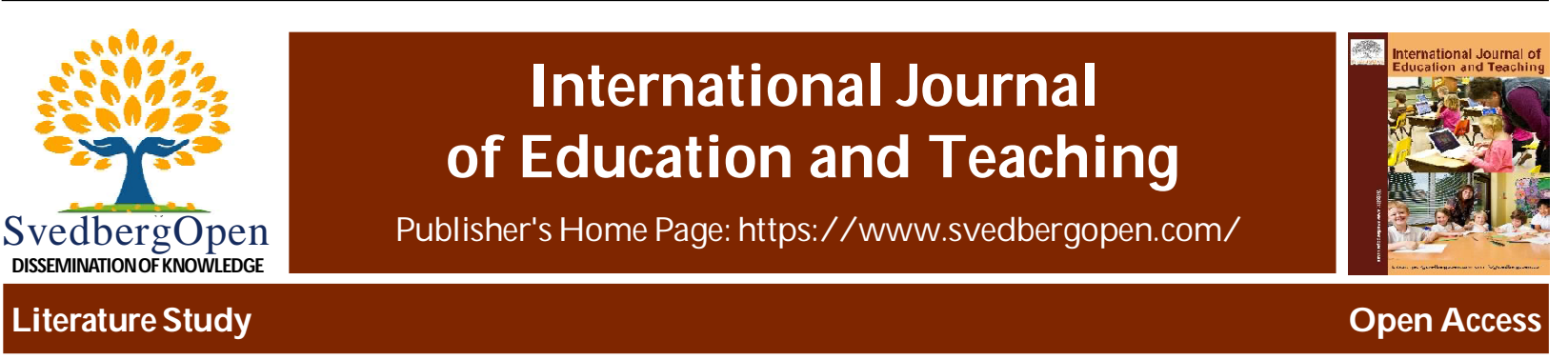

\title{
The Image of Teachers and Children in Shirley Jackson's Story Charles: A Pedagogical and Literature Study
}

\section{Latifah Maurinta Wigati ${ }^{*}$}

${ }^{1}$ Indonesian Language Education Master Program, Post Graduate Program, Indonesian Education University, , Setiabudhi Street. 229 Bandung, Indonesia. E-mail: 1.maurinta.wigati@gmail.com

Article Info

Volume 1, Issue 3, September 2021

Received : 18 February 2021

Accepted : 12 August 2021

Published : 05 September 2021

doi: 10.51483/IJEDT.1.3.2021.7-12

\section{Abstract}

This study aims to identify the image of teachers and students in literary works. Apart from being a means of expression and expressing ideas, literature can be used as learning material. Learning values in literary works are not conveyed explicitly like in non-fiction works, but are implicit in a beautiful series of words. Based on this study, it was found that teachers used the reward and punishment method in educating their students. This study is a descriptive qualitative study. Data in the form of words, sentences and phrases related to pedagogical aspects.

Keywords: Student, Teacher education, Pedagogical literature

(c) 2021 Latifah Maurinta Wigati. This is an open access article under the CC BY license (https://creativecommons.org/licenses/by/4.0/), which permits unrestricted use, distribution, and reproduction in any medium, provided you give appropriate credit to the original author(s) and the source, provide a link to the Creative Commons license, and indicate if changes were made.

\section{Introduction}

Literature is the fourth path of truth after religion, philosophy and science.

$$
\text { - Aristotle }
$$

From this quotation, literature is aligned with three ways of truth. Literature is indeed fictitious. However, it contains the values of life in it. Learning literature is synonymous with learning life.

There are various kinds of literary texts including novels, novella, short stories, poetry and drama. In this study, the writer will narrow down the discussion of literary texts to be limited to short stories.

Short stories are the shortest type of prose. In other words, a short story can be read in only one moment. Reading short stories doesn't take long. In the short story, there is only one conflict that continues to make an impression from beginning to end.

Just like other types of prose, short stories have intrinsic elements. The intrinsic elements include:

1. Figure: Characters and characterizations are important elements in a short story. Characters are the movers of the story. Without characters, a story will not live.

2. Plot: Flow is a systematic story from beginning to end. There are several types of grooves such as forward grooves, reverse grooves, and mixed grooves. The forward plot moves the story from start to finish without any flashbacks.

\footnotetext{
* Corresponding author: Latifah Maurinta Wigati, Indonesian Language Education Master Program, Post Graduate Program, Indonesian Education University, , Setiabudhi Street. 229 ${ }^{\text {th }}$,Bandung, Indonesia. E-mail: l.maurinta.wigati@gmail.com
} 
The backward plot tells the story from the ending point then moves slowly to the beginning with flashbacks. Meanwhile, the mixed plot uses flashbacks in the middle of the story.

3. Background: The setting is an atmosphere that builds a story. A good writer will do in-depth research into the setting of the story. There are three types of setting in the story, namely the setting of the place, the setting of time, and the setting of the atmosphere. There are also writers are given the option to choose a setting according to real life or an alternative setting to build a story.

4. Mandate: As discussed earlier, literature contains life value. This value of life is called mandate. Mandate does not always have to be presented through the value of goodness, but also in the bad events in a story. Through bad events, readers are invited to avoid or not imitate these things in life.

5. Theme: Themes are the main ideas expressed in a story. A story can raise several themes at once. However, short stories usually only carry one big theme.

6. Viewpoint: Point of view is the way the storyteller/author places himself in the story. Three types of viewpoints are the first person perspective (using the pronoun I, I), the second person perspective (a point of view that is rarely used, because it uses your pronoun to engage the reader), and the third person perspective (using the pronoun he uses). ). Each point of view has its own advantages and disadvantages in exploring the story. The type of point of view that is widely used is the third person point of view.

In addition to the six intrinsic elements above, there are story building elements from outside the story structure called extrinsic elements. The extrinsic element relates to the author and social setting when a story is written.

A literary work cannot be separated from the social situation at the time of its creation. A writer or writer has its own mission or idealism in writing literary works. There are messages, ideas, and thoughts he wants to convey to readers.

Literary works have practical uses. Practical uses include fulfilling recreational, educational, inspiring, entertaining, fun to read, and useful functions. This practical utility is in accordance with epistemic benchmarks as stated by Pradopo (2002).

A good literary work not only entertains its readers, but also provides lessons and values for life. Educational values can also be conveyed through literature. This type of literary work for educational and teaching purposes is called didactic literature. There are didactic literary works written purely for teaching materials or educational purposes. However, there is also a didactic element implied in other literary works that are not made specifically for educational purposes. Examples of didactic literary works include religious novels by Habiburahman El Shirazy, Tottto-chan by Tetsuko Kuroyanagi, and Laskar Pelangi by Andrea Hirata. The latter two novels are even set in school. Laskar Pelangi is set in a private school on the outskirts of the island of Belitung. Totto-chan is set in a unique school in Tokyo.

Didactic literature is inseparable from pedagogical elements. Pedagogical aspects are highlighted in literary works of this type. The pedagogical scope is not only centered in the school environment, but can also be demonstrated in the family environment through the interaction of children and parents.

Due to the importance of pedagogical aspects in didactic literary works, the researcher intends to study literary works from a pedagogical point of view. There is also a literary work studied is a classic short story entitled Charles by Shirley Jackson. In this study, two research questions can be drawn as follows:

1. What is the image of the teacher and student in the short story Charles by Shirley Jackson?

2. What educational methods did the teacher use in Shirley Jackson's Charles short story?

This study is qualitative in nature. Qualitative study is a study that produces descriptive data in the form of words. The data taken are in the form of words, phrases, and sentences showing the pedagogical aspects of the short story Charles by Shirley Jackson. The data collection method is carried out through the following steps:

1. Read Shirley Jackson's Charles short story.

2. Understand the content of the short story Charles by Shirley Jackson.

3. Separating words, phrases and sentences that contain pedagogical elements in the short story Charles by Shirley Jackson.

Wonmaly (2019) examines the pedagogical aspects and genetic structure in the novel Athirah by Alberthian Indah. Kusumastuti (2009) examines the pedagogical aspects of Dian Nuranindya's novel Dealova. The novelty element that distinguishes this research from previous studies is the disclosure of educational methods conveyed in literary works. 
If the previous research only discussed pedagogical aspects such as religious and other aspects, this study discussed the educational methods used by the teacher in the story. This study can add references for teachers and teaching materials for students.

\section{Theoretical Foundation}

Pedagogical originates from Greek. Pedos which means boy and egogos which means to deliver. Literally, it means a maid who takes a boy. In Ancient Greece, one of the servants' jobs did take boys to school. However, in its development, pedagogy is defined as an expert who guides children to independently complete their life tasks. It can be said that pedagogy is the art of educating children to reach maturity.

Children are defined as humans who are still small. Unlike adults, children have not been given big responsibility. Childhood is a period of learning. Children learn until they are independent.

Pedagogical is the nature of thoughts and reflections on how to educate/guide children. The concepts in pedagogy include the essence of man, the essence of the child, and the essence of the educational process. Pedagogy is very important in the educational process of children.

According to Hoogeveld, educating is helping a child so that one day the child is able to complete his life's tasks on his own responsibility. S. Brojonegoro stated that to educate means to provide guidance to immature humans. Meanwhile, according to Ki Hajar Dewantara, educating is guiding all the strengths inherent in children so that they get the highest safety and happiness.

The description above suggests that the object of pedagogical study is the scope of education between adults and children. Pedagogy lasts from birth to adulthood. The pedagogical aspect encourages humans to become animal educandum (creatures who need education).

In educating children, there are various educational methods. One of them is the reward and punishment method. This method teaches children to behave well. Punishment shows what children should not do and rewards are given when children do what they should do. When a child makes a mistake or breaks the rules, he gets punished. Punishment is usually given by teachers and parents. On the other hand, children get prizes when they do something good or excel. Punishment according to Purwanto (2007) is suffering that is given/inflicted on purpose after a violation or crime occurs. The child is expected to regret his offense after receiving punishment.

The form of sanction or punishment can be in the form of physical and psychological punishment. Punishment can range from a mere cold stare to a beating on the body. No educational expert really makes punishment as an option unless forced. Gifts or praise are more important to use (Tafsir, 2008).

Sahlan (2009) suggests several ways of giving gifts, including:

1. Choose an attractive gift

2. Make sure the gifts match the standards of behavior

3. Establish a gift-giving procedure

4. Give gifts fairly

5. Give gifts at the right time

Giving punishment also requires various considerations, including the following:

1. Giving punishment fairly according to the severity of the mistakes.

2. Punishment should not hold a grudge in the child's heart.

3. Punish by educating and not hurting.

4. The child is given an understanding of why he is being punished.

5. Punishment is expected to give awareness and regret to children.

Punishment and reward cannot be given at random. The giving of gifts is intended for habituation. When habituation is achieved, gift giving should be reduced. There are also several purposes for giving gifts are:

1. Reducing negative student behavior.

2. Encourage positive and productive behavior.

3. Motivate children's enthusiasm for learning. 
4. Encourage children towards divergent thinking.

5. Increase children's attention to learning.

The punishment has five purposes, namely:

1. In retaliation

2. As an improvement

3. As a protection against society from evil deeds

4. As compensation

5. As a way of scaring

Prizes don't have to be in-kind. Things that can be categorized as gifts include:

1. Praise: The effect of praise is felt on a person's mental. Praise can motivate children to do good.

2. Ranks and symbols: Ratings are usually expressed in letters and numbers. Symbols can be asterisks, certificates, etc.

3. Appreciation: A sign of appreciation can be in the form of a plaque/medal or the child's best work displayed in the class.

Types of punishment include:

1. Decrease in value/ranking

2. Deduction of rights

3. Penalty fine

4. Giving reproach

5. Social sanctions in the form of exclusion

6. Detention at school and suspension

7. Referrals

\section{Discussion}

Charles's short story was written by Shirley Jackson. Charles was published in Mademoiselle magazine in 1916. An Indonesian writer, Magie Tiogakin, translated this short story into Indonesian.

Charles tells of a little boy named Lauri. Every time she comes home from school, Lauri always tells about the stubbornness of her classmate named Charles. Her story was so convincing that her parents believed that Charles really existed. They even felt that Charles had a bad influence on Lauri. Lauri's mother was eager to meet Charles's mother. One day, the kindergarten where Lauri went to school held a meeting of parents. Lauri's mother looks for Charles's parents. However, he also did not find it. Throughout the meeting there was not even a mention of Charles's name. At the end of the story, it is revealed that the Charles Lauri often talks about is actually himself.

In the short story, Lauri is described as an impolite child. This is evidenced in the quote:

Quote 1:

He didn't even remember to turn around and wave at me from the corner like he always did.

Quote 2:

After school, Laurie was still the same. The front door was pushed violently, his hat was allowed to fall on the floor, and his deafening scream echoed through the house: "Is there anyone?"

The first quote shows that Lauri alias Charles did not say goodbye to his mother before leaving for school. The second quote shows that Lauri alias Charles came home from school without greeting. He even violently opened the door of the house.

Another image that appears in Lauri is stubborn. Its stubbornness is shown in the quote:

Quote 1:

On the first day my son Laurie entered kindergarten, he refused to wear corduroy pants and a bib. 
Quote 2:

"His friend is a man who makes us have to do physical training. We are asked to touch our toes. See." Laurie got out of her chair, crouched down, and touched her toes. "Like this," he said. He sat back down in his chair and said, raising a fork, "Charles didn't do anything."

"Charles kicked Teacher's friend," said Laurie. "Teacher's friend asked Charles to touch his toes like I did just now, and Charles kicked him instead."

Quote 2:

He reluctantly answered his father's questions, spilled the milk of his younger brother, who was still a toddler, and announced a message from his teacher that we as parents are prohibited from swearing or tarnishing God's name in our daily conversation.

Quote 3:

"Today Charles beat up the Teacher."

The form of stubbornness of Lauri alias Charles in the first quotation is shown when he refused to attend sports lessons. The second quote shows the stubbornness of Lauri alias Charles at home. She spilled the milk of her toddler sister and lazily answered her father's question. Lauri alias Charles is seen at school when he hits his teacher.

The teacher figure in this short story is described as an educator who likes to punish his students. The method of punishment is shown in the quote:

Quote 1:

"He spoke wrong. The teacher beat him and put him in front of the class."

Quote 2:

"Charles wanted to color with green crayons, so he hit the teacher and the teacher hit him back and threatened all the students in the class not to play with Charles. But they still play with Charles."

Quote 3:

On the third day-Wednesday-Charles is said to have flung a saw and saw log over a student's head until it bled. The teacher finally forbade Charles to leave the classroom during recess. On Thursday, Charles was dropped off in the corner of the classroom during class because he didn't want to stop stomping the floor. On Fridays, Charles was forbidden from touching the classroom blackboard because he threw a stick of chalk.

Quote 4:

"Charles shouted loudly and a first grader was sent to report it to the teacher, so the teacher had to silence Charles, and Charles was punished after school. So all the kids stay in the classroom to watch Charles."

Quote 5:

Monday morning, Charles forgot about the girl and said the bad word three or four times, until the Teacher washed her mouth over and over again. He also threw chalk.

From the five quotes above, it can be seen that the teacher gave varied punishments for Charles alias Lauri. Corporal punishment in the form of spanking, strap punishment, deduction of rights in the form of not being able to touch the board, and exclusion by prohibiting other children from playing with Charles. Another form of punishment is washing Charles's mouth with soap for saying bad words.

There are also gifts of less frequency. The giving of gifts is reflected in the quote:

Quote 1:

"Charles was so nice that the teacher gave him an apple."

The teacher gave Charles a gift of objects. That, too, only once. Gift giving was less frequent than punishment. This contradicts the agreement of educational experts to increase reward / praise over punishment. The teacher in this story often punishes his students.

\section{Conclusion}

From the above studies, it can be concluded that: 
1. The child image in the short story Charles by Shirley Jackson is a naughty and naughty child.

2. The teacher's image in the short story Charles by Shirley Jackson is that of a harsh educator and convict.

3. Teachers use reward and punishment methods in educating their students.

4. The punishments given by the teacher are varied, ranging from beatings, punishment for exclusion, withdrawal, reduction of rights, to sanctions of exclusion.

5. The proportion of rewards and penalties is greater. Penalties can be given many times a week, while prizes are only given once.

6. The teacher's choice to punish repeatedly contradicts the opinion of educational experts who only use punishment when forced and further increase reward/praise.

\section{References}

Jackson, Shirley. (1916). Charles. [online] available at http://fiksilotus.com/charles accessed on March 232021.

Kusumastuti, Tsani. (2009). Analisis Struktural dan Aspek Pedagogis Novel Dealova karya Dian Nuranindya. [online] available at digilib.uns.ac.id/document/analisis-struktural-genetik-dan-aspek-pedagogis-novel-teenlit-dealova-karyadian-nuranindya. Accesed on March 23, 2021.

Purwanto, Ngalim. (2007). Psikologi Pendidikan Remaja. Bandung: Rosdakarya.

Pradopo, Rachmat Joko. (2002). Kritik Sastra Indonesia Modern. Yogyakarta: Gamma Media.

Wonmaly, Windy. (2019). Analisis Struktur Genetik dan Aspek Pedagogis dalam Novel Athirah karya Alberthian Endah. Jurnal Literasi, 3(1).

Sahlan, Asmaun. (2009). Mewujudkan Budaya Religius di Sekolah: Upaya Mengembangkan PAI Dari Teori ke Aksi. Malang: UIN Maliki.

Tafsir, Ahmad. (2008). Ilmu Pendidikan dalam Perspektif Pendidikan Islam. Bandung: Remaja Rosdakarya.

Cite this article as: Latifah M aurinta Wigati (2021). Thel mage of Teachers and Children in Shirley Jackson's Story Charles: A Pedagogical and Literature Study. International Journal of Education and Teaching. 1(3), 7-12. doi: 10.51483/ IJEDT.1.3.2021.7-12. 